\title{
Effect of Mixed Micellar Lipid on the Absorption of Cholesterol and Vitamin $\mathrm{D}_{3}$ into Lymph
}

\author{
Gilbert R. Thompson, Robert K. Ockner, and \\ KURT J. ISSELbacher \\ From the Department of Medicine, Harvard Medical School and the Medical \\ Services (Gastrointestinal Unit), Massachusetts General Hospital, \\ Boston, Massachusetts 02114
}

\begin{abstract}
A B S TRACT The absorption of endogenous cholesterol, labeled with tracer doses of cholesterol ${ }^{14} \mathrm{C}$ or cholesterol- ${ }^{3} \mathrm{H}$ and of near physiological doses of vitamin $\mathrm{D}_{3}{ }^{3} \mathrm{H}$ was studied in rats with cannulated intestinal lymphatics. The effects of administering mixed micellar solutions of fatty acid, monoglyceride, and bile salt on the absorption of these labeled sterols was determined. It was observed that the specific activity of free cholesterol and the amounts of vitamin $\mathrm{D}_{3}$ appearing in lymph were significantly increased during the intraduodenal administration of mixed micellar solutions of either linoleic or palmitic acid, in contrast to control rats receiving a micellar solution of taurocholate. These increases were related linearly to the lymph triglyceride level. In addition it was observed that when the linoleic acid solution was administered there was a more marked increase in the ratio of the specific activities of free and esterified cholesterol in lymph than with either the palmitic acid or taurocholate solutions.
\end{abstract}

Additional studies in rats with intact lymphatics showed that the uptake of labeled cholesterol and vitamin $\mathrm{D}_{3}$ from the intestinal lumen into the wall was similar whether the sterols were administered in taurocholate or in mixed micellar solution.

These findings suggest that mixed micellar lipid increased the rate of appearance of labeled free cholesterol and vitamin $\mathrm{D}_{3}$ in lymph by enhancing their transport out of the intestinal mucosa, rather than by an effect on uptake.

\section{INTRODUCTION}

Cholesterol and vitamin $\mathrm{D}_{3}$ are sterols of similar molecular structure, and both are absorbed from the small

Dr. Thompson's present address is Department of Medicine, Royal Postgraduate Medical School, Ducane Road, London W 12, England.

Received for publication 30 April 1968 and in revised form 1 August 1968. intestine primarily via the lymphatic route $(1,2)$. Their absorption differs, however, in that cholesterol is largely reesterified before entering the lymph (3), whereas vitamin $\mathrm{D}$ is absorbed mainly as the free sterol $(2,4)$. Although several groups of investigators have reported that the absorption of cholesterol is increased by dietary fat $(5-8)$, these studies have often involved administration of unphysiologically large amounts of both fat and cholesterol. There is also some indirect evidence that dietary fat may enhance the absorption of vitamin D (9).

The means by which dietary fats influence sterol absorption have not been clearly determined. However, it has been suggested (10) that fat may enhance cholesterol absorption either by $(a)$ a stimulatory effect on bile flow; $(b)$ providing an increased supply of fatty acids for cholesterol esterification; or (c) promoting the formation of mixed micelles in the intestinal lumen, thus increasing the solubility of the sterol (11). The first and third of these possible mechanisms might also apply to vitamin D. However, to date there has been no clear definition of their relative importance.

The present study, therefore, was primarily designed to determine the effect of lipid absorption on the transport of labeled cholesterol and vitamin $\mathrm{D}_{3}$ into intestinal lymph, under conditions such that the mucosal uptake of these sterols would not be affected by differences in their solubilities within the intestinal lumen. Trace quantities of the radioactive sterols, dissolved in solutions of either bile salt micelles or mixed micelles (fatty acid-monoglyceride-bile salt) were administered intraduodenally to rats with cannulated intestinal lymphatics. By this means intraluminal cholesterol was labeled, and the effect of exogenous fat upon the transport of endogenous cholesterol and exogenous vitamin $\mathrm{D}$ could be determined.

\section{METHODS}

Materials. Cholesterol-4- ${ }^{14} \mathrm{C}$, cholesterol-1,2- ${ }^{8} \mathrm{H}$, vitamin $\mathrm{D}_{3}-1,2-{ }^{8} \mathrm{H}$, palmitic acid-1-14 $\mathrm{C}$ and linoleic acid-1- ${ }^{14} \mathrm{C}$ were 
obtained from a commercial source. ${ }^{1}$ All were found to be greater than $99 \%$ pure on thin-layer chromatography except for vitamin $\mathrm{D}_{3}-1,2-{ }^{3} \mathrm{H}$ which was $90-94 \%$ pure. When the purity fell below $90 \%$ it was repurified before use by methods previously described (12).

The following unlabeled materials were obtained commercially : palmitic acid, ${ }^{2}$ oleic acid and linoleic acid, ${ }^{3}$ monopalmitin, ${ }^{4}$ monoolein, ${ }^{3}$ and sodium taurocholate. ${ }^{3,5}$ The fatty acids were all more than $99 \%$ pure. The monoolein (glyceryl-1-monooleate) was only $90 \%$ pure, the remaining $10 \%$ consisting mainly of fatty acid and diglyceride on thin-layer chromatography. The sodium taurocholate contained traces of cholic acid but no deoxycholic acid on thin-layer chromatography.

Preparation of micellar solutions. Mixed micellar solutions were prepared by drying down benzene solutions of fatty acid and monoglyceride on a rotary evaporator and redissolving the lipid in $40 \mathrm{~mm}$ taurocholate as described by Johnston and Borgström (13). This solution was then diluted with an equal volume of $0.15 \mathrm{M}$ saline- $0.1 \mathrm{M}$ phosphate buffer $\mathrm{pH} 7.0(5: 1, \mathrm{v} / \mathrm{v})$, and the $\mathrm{pH}$ brought to 7.4 by the addition of $1 \mathrm{~N}$ sodium hydroxide. The resulting solutions contained $9.6 \mu$ moles of fatty acid, equivalent to $2.46 \mathrm{mg}$ of palmitic acid or $2.69 \mathrm{mg}$ of linoleic acid, and $4.8 \mu$ moles of monoglyceride per $\mathrm{ml}$ of $20 \mathrm{~mm}$ taurocholate. Labeled sterols were added to the benzene solution of fatty acid and monoglyceride in amounts sufficient to provide a single dose in $5 \mathrm{ml}$ of micellar solution. Micellar solutions of taurocholate were prepared by a $1: 1 \mathrm{v} / \mathrm{v}$ dilution of $40 \mathrm{~mm}$ taurocholate with buffered saline, $\mathrm{pH}$ 7.4. The taurocholate was presumed to be largely in the form of bile salt micelles, since $20 \mathrm{~mm}$ is considerably above the critical micellar concentration of 2-5 mM (14).

Characteristics of micellar solutions. All mixed micellar solutions were initially clear and the linoleic acid-monoolein solution remained so at $37^{\circ} \mathrm{C}$. However, as the solutions containing the palmitic acid micelles cooled, they became turbid, presumably because of partial transition from a micellar to a crystalline phase (14). This was slightly more pronounced when monopalmitin was the monoglyceride in the system, and therefore monoolein was substituted for monopalmitin in some of the later experiments. Although the administered palmitic acid mixtures thus contained some crystalline material, they will be designated as "mixed micelles" for the sake of brevity. For convenience linoleic acid-monoolein mixed micelles will henceforth be referred to as linoleic acid mixed micelles, and palmitic acid-monopalmitin and palmitic acid-monoolein mixed micelles will be referred to collectively as palmitic acid mixed micelles.

To assess the distribution of sterol and fatty acid between the micellar and crystalline phases, linoleic acid mixed micelles and palmitic acid mixed micelles were prepared containing tracer amounts of cholesterol-1-2- ${ }^{3} \mathrm{H}$ and the respective fatty acid- ${ }^{14} \mathrm{C}$. These solutions were allowed to equilibrate at $37^{\circ} \mathrm{C}$, and $1 \mathrm{ml}$ amounts were then passed through $10 \mathrm{~m} \mu$ and $50 \mathrm{~m} \mu$ Millipore filters, ${ }^{6}$ each in triplicate. The filters were washed with $2 \mathrm{ml}$ of $5 \mathrm{~mm}$ taurocholate, transferred to counting vials, and dissolved in $12 \mathrm{ml}$ of a dioxane scintillation solution for radioassay (see below). The results showed that in the case of the linoleic acid mixed micelles

1 New England Nuclear Corp., Boston, Mass.

2 Hormel Institute, Austin, Minn.

3 Calbiochem, Los Angeles, Calif.

4 Sigma Chemical Co., St. Louis, Mo.

5 K\&K Laboratories, Plainview, N. Y.

6 Millipore Filter Corp., Bedford, Mass.
83.3 and $86.7 \%$ of the labeled linoleic acid and 82.1 and $90.0 \%$ of the cholesterol passed through 10 and $50 \mathrm{~m} \mu$ filters, respectively. By contrast, only 58.0 and $60.1 \%$ of the labeled palmitic acid in palmitic acid mixed micelles passed through these filters. This finding suggested that over $40 \%$ of the palmitic acid was in a nonmicellar form, since mixed micelles are approximately $5-10 \mathrm{~m} \mu$ in diameter (15). However, there was no hold-up in the passage of the labeled cholesterol in palmitic acid micelles, since 90.5 and $92.5 \%$ passed through the $10 \mathrm{~m} \mu$ and $50 \mathrm{~m} \mu$ filters, respectively. This finding suggested that the labeled cholesterol had a greater affinity for the micellar phase than for the crystalline phase under the present conditions.

Doses of labeled sterols. Cholesterol- $4-{ }^{14} \mathrm{C}(0.1 \mu \mathrm{c})$ was used in tracer amounts to label the endogenous cholesterol within

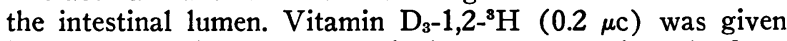
in a dose of $5 \mathrm{~m} \mu$ moles, equivalent to approximately $2 \mu \mathrm{g}$ or $80 \mathrm{IU}$ of vitamin $\mathrm{D}_{3}$. These two isotopes were usually given together. On occasion cholesterol-1-2- ${ }^{3} \mathrm{H}(0.5 \mu \mathrm{c})$ was given alone to rats who had received cholesterol- $4-{ }^{14} \mathrm{C}$ the previous day. In some instances the absorption of fatty acid from the mixed micellar solutions was measured using tracer amounts of palmitic and linoleic acids ${ }^{14} \mathrm{C}(0.1 \mu \mathrm{c})$.

Operative procedures. Nonfasted adult male rats of the $\mathrm{CD}$ strain, ${ }^{7}$ weighing $300-350 \mathrm{~g}$, having previously been on a standard diet, 8 were anesthetized with intraperitoneal pentobarbital. The intestinal lymphatic duct was cannulated before its entry into the cisterna chyli by a modification of the technique of Bollman, Cain, and Grindlay (16). Postoperatively the rats were placed in restraining cages (17) and allowed free access to $5 \%$ dextrose in isotonic saline. Lymph was collected overnight and the volume recorded. The majority of rats undergoing studies of sterol absorption were used on the 1st postoperative day. In four rats studies were carried out on the 2 consecutive days; the results did not differ significantly between the 1 st and 2 nd postoperative days.

In some studies, rats were prepared with intraduodenal catheters but without lymph fistulas. In all other respects handling of the animals was identical.

Absorption studies. Lymph fistula rats were allowed access to dextrose-saline during the basal $1 \mathrm{hr}$ collection of lymph on the morning of the study. At the conclusion of this hour all oral fluids were temporarily withdrawn.

Labeled sterols were administered in $5 \mathrm{ml}$ of $20 \mathrm{~mm}$ taurocholate or mixed micelles. These were given by intraduodenal infusion during the $30 \mathrm{~min}$ period after the basal hour and then washed in with $0.5 \mathrm{ml}$ of $5 \mathrm{~mm}$ taurocholate. 30 min later a second infusion of $5 \mathrm{ml}$ of taurocholate or mixed micelles, containing no labeled sterols, was commenced and maintained slowly over the remainder of the 3-hr period. In a few early experiments, the labeled sterols were administered in $1 \mathrm{ml}$ of $5 \mathrm{~mm}$ taurocholate after the conclusion of an initial $5 \mathrm{ml}$ infusion of unlabeled micelles. Sterol absorption data obtained with these two experimental techniques was similar.

Animals without lymph fistulas but with intraduodenal catheters received only the initial $5 \mathrm{ml}$ infusion over a $30 \mathrm{~min}$ period. $30 \mathrm{~min}$ after the end of the infusion, the animals were sacrificed, the small intestine was excised and washed with $40 \mathrm{ml}$ saline, and then divided into proximal and distal halves. After homogenization lipid was extracted with chloroform: methanol $(2: 1, \mathrm{v} / \mathrm{v})$ by the method of Folch,

\footnotetext{
${ }^{7}$ Charles River Breeding Laboratories, North Wilmington, Mass.

8 Purina Lab Chow, Ralston-Purina Co., Davenport, Iowa.
} 
Lees, and Sloane-Stanley (18). The chloroform phase was dried, redissolved in $5 \mathrm{ml}$ toluene or hexane, and $0.5 \mathrm{ml}$ taken for radioassay.

Collection of samples. Lymph was collected on ice in heparinized containers during the $3 \mathrm{hr}$ period after the dose of labeled sterol. At the end of this period rats were allowed access to fluid ad lib. Further collections of lymphs were made from 3 to $6 \mathrm{hr}$ and from 6 to $24 \mathrm{hr}$. (The lymph flow during these experiments averaged about $2-3 \mathrm{ml} / \mathrm{hr}$.)

In some instances lymph-fistula rats were then sacrificed, their intestinal tract removed, and its radioactivity determined, together with that of its contents and feces, as was described above. The small and large intestinal contents were homogenized separately with saline in a Waring blendor. The total volume of each was recorded and $0.5 \mathrm{ml}$ taken for radioassay.

Measurement of radioactivity. Radioactivity was measured in a Beckman LS-200 liquid scintillation counter using an external standard ratio to correct for quenching. Lymph samples were assayed for radioactivity by adding $0.2-0.5 \mathrm{ml}$ to $12 \mathrm{ml}$ of a scintillation solution consisting of 2,5-diphenyloxazole (PPO), $7.0 \mathrm{~g}$, p-bis[2-(5-phenyloxazolyl]benzene (POPOP), $0.05 \mathrm{~g}$, naphthalene, $50 \mathrm{~g}$, and $95 \%$ ethanol, 154 $\mathrm{ml} /$ liter of dioxane. This procedure gave identical results in terms of disintegrations per minute per milliliter of lymph with those obtained by extracting $1 \mathrm{ml}$ of lymph with chloroform:methanol and then counting the dried chloroform phase in $15 \mathrm{ml}$ of a liquid scintillation solution consisting of PPO, $4 \mathrm{~g}$, and POPOP, $0.05 \mathrm{~g} /$ liter of toluene. The degree of quenching with lymph in the dioxane system was similar to that of an equal volume of water. Doses of labeled sterol were counted routinely by adding $0.5 \mathrm{ml}$ to the dioxane scintillation solution, and this procedure was also used to count intestinal content. Any other lipid-soluble radioactivity was counted in the toluene scintillation solution.

Nature of radioactivity in lymph. After administration of labeled cholesterol and vitamin $\mathrm{D}$, most radioactivity appeared in lymph between 0 and $6 \mathrm{hr}$. Lymph samples taken during this period were extracted and then chromatographed on thin-layer plates of silicic acid, with chloroform as the solvent. Markers of free and ester cholesterol and vitamin $\mathrm{D}_{3}$ were run at the same time. At the conclusion the marker strips were sprayed with $30 \%$ sulphuric acid and heated. The plate was divided horizontally into $1 \mathrm{~cm}$ strips, and the silica gel was scraped into counting vials and counted in $15 \mathrm{ml}$ of toluene scintillation solution.

With cholesterol- $4-{ }^{14} \mathrm{C}$, it was found that $96.7 \%$ of the radioactivity recovered had moved similarly to either free cholesterol $(19.4 \%)$ or cholesterol ester $(77.3 \%)$, the remaining $2.4 \%$ staying at the origin. With vitamin $\mathrm{D}_{3}-1,2{ }^{8} \mathrm{H}$, $77.8 \%$ of the radioactivity recovered had moved as vitamin $\mathrm{D}_{3}, 5.9 \%$ was located in the sterol ester region, $5.3 \%$ remained at the origin, and $8.7 \%$ ran between the origin and the free sterol zone, i.e., was more polar than vitamin D.

Analytical techniques. Lymph triglycerides were determined by the method of van Handel and Zilversmit (19). Lymph total cholesterol was determined by a modification of the method of Zlatkis, Zak, and Boyle (20). Samples of whole lymph were first saponified for $1 \mathrm{hr}$ in potassium hydroxide in $50 \%$ ethanol, $v / v$ at $60^{\circ} \mathrm{C}$; the sterols were subsequently extracted with hexane, dried, and dissolved in glacial acetic acid for assay. By this technique saponifiable lipids which interfered with the color determination were removed.

Lymph free and ester cholesetrol were determined as follows: $1-\mathrm{ml}$ samples of lymph were extracted with chloroform: methanol (18). The chloroform phase was separated, dried, and redissolved in hexane. $2 \mathrm{~g}$ of silicic acid, Bio-Sil BH 100-200 mesh, ${ }^{9}$ were slurried in hexane and poured into $12 \times 0.5$ inch glass columns. The lymph lipid extract was then loaded onto the column and eluted first with $30 \mathrm{ml}$ of $4 \%$ diethyl ether in hexane (fraction 1 ), followed by $30 \mathrm{ml}$ of $100 \%$ diethyl ether (fraction 2). By use of markers of cholesterol-4- ${ }^{14} \mathrm{C}$ and cholesterol- $7 \alpha{ }^{3} \mathrm{H}$ palmitate, ${ }^{1}$ the latter being purified by thin-layer chromatography beforehand, it could be shown that fraction 1 contained $98.6 \%$ of the cholesterol ester recovered, the total recovery being $98.6 \%$, and that fraction 2 contained $99.1 \%$ of the free cholesterol recovered, the total recovery being $98.8 \%$.

Each fraction was dried down on a rotary evaporator and redissolved in $10 \mathrm{ml}$ hexane, of which $5 \mathrm{ml}$ were taken for chemical determination of cholesterol. The remaining $5 \mathrm{ml}$ were dried and dissolved in $15 \mathrm{ml}$ of toluene scintillation solution for radioassay. Chemical determination of the free and ester cholesterol fractions were then carried out as previously described.

Statistical methods. Differences between the three groups of lymph fistula rats have been calculated by the analysis of variance, using the statistic $F$.

$$
F=\frac{\text { variance between groups }}{\text { variance within groups }}
$$

The $P$ value which corresponds to the value of $F$ indicates the probability that the groups were drawn from one homogeneous population. Where the value of $P$ is low this suggests that one or more of the groups differs significantly from the others; which groups differed could usually be determined by inspection of the means.

\section{RESULTS}

Uptake of labeled cholesterol. The effect of taurocholate micelles or mixed micellar solutions on the uptake of a tracer dose of cholesterol $-{ }^{14} \mathrm{C}$ in rats without lymph fistulas was studied. In Table $I$ it will be seen that the amount of radioactivity recovered from the intestinal contents at $1 \mathrm{hr}$ was least in rats given taurocholate $(7.9 \%)$ and was slightly higher in both groups given mixed micelles (11.4 and $11.0 \%$ ). The amount of radioactivity in the small intestinal wall was similar in all three groups, mean values ranging between 69.4 and $76.5 \%$. The over-all mean recovery of radioactivity was also similar in the three groups, ranging from 80.8 to $84.8 \%$. These results indicate that at the end of $1 \mathrm{hr}$ the uptake of labeled cholesterol from the intestinal lumen was no greater from mixed micelles than from taurocholate micelles. The distribution of radioactivity between proximal and distal halves of intestine was also similar in all three groups, $90.2-92.1 \%$ of the radioactivity in the wall being in the proximal half.

Uptake of labeled vitamin Ds. As indicated in Table II, the amount of radioactivity remaining within the intestinal lumen at $1 \mathrm{hr}$ was similar in the three groups, mean values ranging between 16.1 and $20.9 \%$. These values were higher than those for cholesterol.

\footnotetext{
9 Bio-Rad Laboratories, Richmond, Calif.
} 
TABLE I

Effect of Taurocholate Micelles or Mixed Micelles on the Uptake of a Tracer Dose of Cholesterol ${ }^{14} \mathrm{C}$ at $1 \mathrm{hr}$

\begin{tabular}{cccc}
\hline & \multicolumn{2}{c}{$\begin{array}{c}\text { Per cent of administered } \\
\text { radioactivity* }\end{array}$} & \\
\cline { 2 - 3 } Micelles $¥$ & $\begin{array}{c}\text { Small and } \\
\text { large intes- } \\
\text { tinal contents }\end{array}$ & $\begin{array}{c}\text { Small intes- } \\
\text { tinal wall }\end{array}$ & $\begin{array}{c}\text { Total re- } \\
\text { covery }\end{array}$ \\
\hline Taurocholate & 7.9 & 76.5 & 84.4 \\
Linoleic acid & $(6.5-9.2)$ & $(75.5-78.5)$ & $(82.1-87.7)$ \\
Palmitic acid & 11.4 & 69.4 & 80.8 \\
& $(9.4-12.8)$ & $(64.3-75.8)$ & $(77.1-85.2)$ \\
& $(11.0$ & 73.8 & 84.8 \\
& $(10.5-11.8)$ & $(72.1-75.6)$ & $(83.9-86.3)$
\end{tabular}

* Mean and range. There were three rats in each group.

$\ddagger$ Taurocholate micelles contained $20 \mathrm{MM}$ taurocholate. Linoleic acid mixed micelles contained linoleic acid and monoglyceride in $20 \mathrm{mM}$ taurocholate. Palmitic acid mixed micelles contained palmitic acid and monoglyceride in $20 \mathrm{mM}$ taurocholate.

Both the over-all recovery of radioactivity and that recovered from the intestinal wall at $1 \mathrm{hr}$ were highest in the taurocholate group. Luminal radioactivity was similar in all three groups. These results suggest that although uptake of vitamin $\mathrm{D}_{3}$ was similar among the three groups, there was an increased transport of vitamin $\mathrm{D}$ out of the intestinal wall in rats given mixed micelles, as compared to those which received taurocholate micelles. The distribution of radioactivity between proximal and distal halves of intestine was also similar in the three groups, $76.0-78.5 \%$ of the radioactivity in the wall being in the proximal half.

Lymph triglycerides. The effect of the intraduodenal infusion of taurocholate micellar or mixed micellar solu-

TABLE II

Effect of Taurocholate Micelles or Mixed Micelles on the Uptake of a 5 mumole Dose of Vitamin $D_{3}{ }^{3} \mathrm{H}$ at $1 \mathrm{hr}$

\begin{tabular}{cccc}
\hline & \multicolumn{2}{c}{$\begin{array}{c}\text { Per cent of administered } \\
\text { radioactivity* }\end{array}$} & \\
\cline { 2 - 3 } Micelles & $\begin{array}{c}\text { Small and } \\
\text { large intes- } \\
\text { tinal contents }\end{array}$ & $\begin{array}{c}\text { Small intes- } \\
\text { tinal wall }\end{array}$ & $\begin{array}{c}\text { Total re- } \\
\text { covery }\end{array}$ \\
\hline Taurocholate & 19.9 & 59.2 & 79.2 \\
& $(16.2-23.0)$ & $(57.1-62.3)$ & $(78.5-80.1)$ \\
Linoleic acid & 20.9 & 45.8 & 66.8 \\
Palmitic acid & $(17.7-23.2)$ & $(42.0-52.6)$ & $(63.9-70.3)$ \\
& 16.1 & 52.9 & 69.0 \\
& $(12.9-20.3)$ & $(47.9-56.4)$ & $(68.2-69.8)$ \\
\hline
\end{tabular}

* Mean and range. There were three rats in each group. tions on lymph triglycerides is shown in Table III. The amount of triglyceride present during the basal hour varied somewhat, the mean values for the three groups of rats being $3.6,6.4$, and $7.2 \mathrm{mg} / \mathrm{hr}$.

The administration of $10 \mathrm{ml}$ of $20 \mathrm{~mm}$ taurocholate over $3 \mathrm{hr}$ had no significant effect on the level of the lymph triglycerides. However, the administration of mixed micellar solutions caused the expected increase in triglycerides during the $0-3 \mathrm{hr}$ and 3-6 hr periods. In the case of linoleic acid mixed micelles the level rose to $12.7 \mathrm{mg} / \mathrm{hr}$ between 0 to $3 \mathrm{hr}$, decreasing to 9.0 $\mathrm{mg} / \mathrm{hr}$ between 3 and $6 \mathrm{hr}$. The levels after the administration of palmitic acid mixed micelles were not as high, being $10.0 \mathrm{mg} / \mathrm{hr}$ between 0 to $3 \mathrm{hr}$ and $6.3 \mathrm{mg} / \mathrm{hr}$ between 3 to $6 \mathrm{hr}$. This apparent difference between the latter two groups may have been due in part to the lower basal triglyceride level in rats given palmitic acid mixed micelles. In all three groups the lymph triglycerides returned to basal levels between 6 and $24 \mathrm{hr}$.

Absorption of labeled fatty acid into lymph. As shown in Table III the administration of palmitic acid mixed micelles resulted in lower lymph triglyceride levels than did administration of linoleic acid mixed micelles. In an attempt to further examine these differences $5 \mathrm{ml}$ of mixed micellar solutions labeled with tracer doses of fatty acids $-{ }^{14} \mathrm{C}$ were administered intraduodenally to lymph fistula rats. In two rats given linoleic acid- ${ }^{14} \mathrm{C}$ mixed micelles 82.3 and $83.3 \%$ of the linoleic acid was absorbed into the lymph in $3 \mathrm{hr}$. By comparison, in four rats given palmitic acid- ${ }^{14} \mathrm{C}$ mixed micelles the absorption of palmitic acid ranged from $46.4 \%$ (palmitic acidmonoolein) to $57.4 \%$ (palmitic acid-monopalmitin). These results indicate that palmitic acid was less completely absorbed into lymph than linoleic acid during

TABLE III

Effect of Intraduodenal Infusion of Taurocholate Micelles or Mixed Micelles on Lymph Triglycerides

\begin{tabular}{|c|c|c|c|c|}
\hline \multirow[b]{2}{*}{ Micelles } & \multicolumn{4}{|c|}{ Lymph triglycerides* } \\
\hline & Basal hrf & $0-3 \mathrm{hr}$ & $3-6 \mathrm{hr}$ & $6-24 \mathrm{hr}$ \\
\hline & \multicolumn{4}{|c|}{$m g / h r$} \\
\hline $\begin{array}{l}\text { Taurocholate } \\
(n=7) \S\end{array}$ & $6.4 \pm 5.8$ & $5.2 \pm 2.2$ & $4.1 \pm 1.9$ & $4.5 \pm 0.9$ \\
\hline $\begin{array}{l}\text { Linoleic acid } \\
\quad(n=7)\end{array}$ & $7.2 \pm 2.0$ & $12.7 \pm 3.4$ & $9.0 \pm 3.1$ & $4.2 \pm 1.0$ \\
\hline $\begin{array}{l}\text { Palmitic acid } \\
\quad(n=11)\end{array}$ & $3.6 \pm 1.8$ & $10.0 \pm 2.5$ & $6.3 \pm 1.5$ & $5.0 \pm 1.5$ \\
\hline
\end{tabular}

$\S n=$ number of rats in each group. 
TABLE IV

Effect of Taurocholate Micelles or Mixed Micelles on the Total Cholesterol of Intestinal Lymph

\begin{tabular}{|c|c|c|c|c|}
\hline \multirow[b]{2}{*}{ Micelles } & \multicolumn{4}{|c|}{ Lymph total cholesterol* } \\
\hline & Basal hr & $0-3 \mathrm{hr}$ & $3-6 \mathrm{hr}$ & $6-24 \mathrm{hr}$ \\
\hline & \multicolumn{4}{|c|}{$m g / h r$} \\
\hline $\begin{array}{l}\text { Taurocholate } \\
\qquad(\mathrm{n}=4) \ddagger\end{array}$ & $\begin{array}{c}0.51 \\
(0.34-0.61)\end{array}$ & $\begin{array}{c}0.54 \\
(0.42-0.64)\end{array}$ & $\begin{array}{c}0.51 \\
(0.41-0.61)\end{array}$ & $\begin{array}{c}0.43 \\
(0.34-0.50)\end{array}$ \\
\hline $\begin{array}{l}\text { Linoleic acid } \\
\quad(\mathrm{n}=4)\end{array}$ & $\begin{array}{c}0.51 \\
(0.38-0.57)\end{array}$ & $\begin{array}{c}0.59 \\
(0.51-0.69)\end{array}$ & $\begin{array}{c}0.59 \\
(0.50-0.77)\end{array}$ & $\begin{array}{c}0.49 \\
(0.33-0.60)\end{array}$ \\
\hline $\begin{array}{l}\text { Palmitic acid } \\
\quad(\mathrm{n}=5)\end{array}$ & $\begin{array}{c}0.48 \\
(0.37-0.53)\end{array}$ & $\begin{array}{c}0.59 \\
(0.53-0.76)\end{array}$ & $\begin{array}{c}0.59 \\
(0.51-0.76)\end{array}$ & $\begin{array}{c}0.55 \\
(0.43-0.71)\end{array}$ \\
\hline
\end{tabular}

* Mean and range.

$\ddagger \mathrm{n}=$ number of rats in each group.

the $3 \mathrm{hr}$ after their administration in mixed micelles. Furthermore, although the substitution of monoolein for monopalmitin as the monoglyceride in palmitic acid mixed micelles resulted in a clearer solution, this did not enhance absorption of the fatty acid.

Lymph total cholesterol. The levels of total cholesterol in lymph, determined chemically, are shown in Table IV. The mean values ranged from 0.43 to 0.59 $\mathrm{mg} / \mathrm{hr}$. Although administration of linoleic acid and palmitic acid mixed micelles resulted in slightly higher cholesterol levels between 0 and $6 \mathrm{hr}$ than did the administration of taurocholate micelles, these differences were not significant.

The effect of intraduodenally administered micelles on the amount of labeled cholesterol appearing in lymph is shown in Table V. Analysis of variance showed that there were no significant differences among the three groups during any of the time periods studied.

TABLE V

Effect of Taurocholate Micelles or Mixed Micelles on the Appearance of Labeled Cholesterol in Lymph

\begin{tabular}{|c|c|c|c|c|}
\hline \multirow[b]{3}{*}{ Micelles } & \multicolumn{4}{|c|}{ Per cent of administered radioactivity } \\
\hline & \multicolumn{3}{|c|}{ Lymph* } & \multirow{2}{*}{$\begin{array}{c}\text { Small intes- } \\
\text { tinal wall } \neq \\
24 \mathrm{hr}\end{array}$} \\
\hline & $0-3 \mathrm{hr}$ & $3-6 \mathrm{hr}$ & $0-24 \mathrm{hr}$ & \\
\hline Taurocholate & $\begin{array}{r}15.7 \pm 4.4 \\
(n=7) \S\end{array}$ & $\begin{array}{c}13.1 \pm 2.1 \\
(n=7)\end{array}$ & $\begin{array}{c}55.8 \pm 9.9 \\
(\mathrm{n}=7)\end{array}$ & $\begin{array}{c}12.6(9.6-19.7) \\
(n=4)\end{array}$ \\
\hline Linoleic acid & $\begin{array}{c}15.1 \pm 2.4 \\
(\mathrm{n}=9)\end{array}$ & $\begin{array}{c}12.9 \pm 3.4 \\
(\mathrm{n}=7)\end{array}$ & $\begin{array}{c}54.3 \pm 5.5 \\
(\mathrm{n}=7)\end{array}$ & $\begin{array}{c}10.5(6.7-16.5) \\
(n=4)\end{array}$ \\
\hline Palmitic acid & $\begin{array}{r}17.3 \pm 2.0 \\
(n=11)\end{array}$ & $\begin{array}{r}15.0 \pm 2.3 \\
(n=10)\end{array}$ & $\begin{array}{c}59.3 \pm 4.4 \\
(\mathrm{n}=9)\end{array}$ & $\begin{array}{c}13.8(9.4-17.2) \\
(n=3)\end{array}$ \\
\hline $\begin{array}{c}\text { Analysis of } \\
\text { variance }\end{array}$ & $\begin{array}{l}F=1.61 \\
P>0.05\end{array}$ & $\begin{array}{l}F=1.69 \\
P>0.05\end{array}$ & $\begin{array}{l}F=1.26 \\
P>0.05\end{array}$ & - \\
\hline
\end{tabular}

* Mean \pm standard deviation.

$\ddagger$ Mean and range. Mean total recovery of radioactivity at $24 \mathrm{hr}$ (including large intestinal contents and feces) was $83.1 \%(n=7)$.

$\S \mathrm{n}=$ number of rats.
TABLE VI

Specific Activity of Lymph Free and Esterified Cholesterol*

\begin{tabular}{|c|c|c|c|c|}
\hline \multirow[b]{3}{*}{ Micelles } & \multicolumn{4}{|c|}{$\begin{array}{l}\text { Per cent of administered radioactivity per } \\
\text { milligram of cholesterol } \neq\end{array}$} \\
\hline & \multicolumn{2}{|c|}{$0-3 \mathrm{hr}$} & \multicolumn{2}{|c|}{$3-6 \mathrm{hr}$} \\
\hline & Free & Ester & Free & Ester \\
\hline $\begin{array}{l}\text { Taurocholate } \\
\qquad(\mathrm{n}=4) \S\end{array}$ & $4.9 \pm 1.4$ & $10.9 \pm 3.0$ & $4.7 \pm 1.5$ & $10.2 \pm 2.2$ \\
\hline $\begin{array}{l}\text { Linoleic acid } \\
\qquad(n=4)\end{array}$ & $8.3 \pm 0.4$ & $9.5 \pm 1.0$ & $6.2 \pm 1.3$ & $10.5 \pm 1.0$ \\
\hline $\begin{array}{l}\text { Palmitic acid } \\
\quad(\mathrm{n}=5)\end{array}$ & $6.8 \pm 1.7$ & $11.3 \pm 2.6$ & $5.5 \pm 0.4$ & $10.1 \pm 1.9$ \\
\hline $\begin{array}{c}\text { Analysis of } \\
\text { variance }\end{array}$ & $\begin{array}{l}F=4.51 \\
P<0.05\end{array}$ & $\begin{array}{l}F=0.48 \\
P>0.05\end{array}$ & & \\
\hline
\end{tabular}

${ }^{*} \mathrm{n}=$ number of rats.

$\ddagger$ Mean \pm standard deviation.

$\S$ The specific activity of each fraction has been calculated as: lymph radioactivity (free or esterified cholesterol) $\times 100$ total administered radioactivity

lymph chemical cholesterol (free or esterified) milligram

$=$ percent of administered dose per milligram.

The amount of radioactivity remaining in the wall of the small intestine at $24 \mathrm{hr}$ after the dose was also similar in the three groups, mean values varying between 10.5 to $13.8 \%$ of the administered dose. The mean overall recovery of radioactivity at $24 \mathrm{hr}$ from lymph, intestinal wall, and intestinal contents was $83.1 \%$.

Specific activity of lymph free and esterified cholesterol. The specific activities of free and esterified cholesterol in lymph between 0 to $3 \mathrm{hr}$ and 3-6 hr are shown in Table VI. The mean values for free cholesterol between 0 to $3 \mathrm{hr}$ were $4.9,8.3$, and $6.8 \% / \mathrm{mg}$ respectively, in rats given taurocholate, linoleic acid, and palmitic acid micelles. These differences were significant $(P<$ $0.05)$. The corresponding values for the $3-6 \mathrm{hr}$ period were $4.7,6.2$, and $5.5 \% / \mathrm{mg}$, these differences being insignificant.

The specific activity of cholesterol ester between 0 to $3 \mathrm{hr}$ was $10.9,9.5$, and $11.3 \% / \mathrm{mg}$ in rats given taurocholate, linoleic acid, and palmitic acid micelles. These differences were not significant. The corresponding values for the 3-6 hour period were $10.2,10.5$, and $10.1 \% / \mathrm{mg}$.

The relationship between the lymph triglyceride content and the specific activity of lymph free cholesterol between 0 to $3 \mathrm{hr}$ is shown in Fig. 1. It will be seen that there was a significant degree of correlation between the two variables $(r=0.64, P<0.02)$. This relationship was independent of changes in lymph flow, since the slope of the regression of the ratio free cholesterol: tri- 


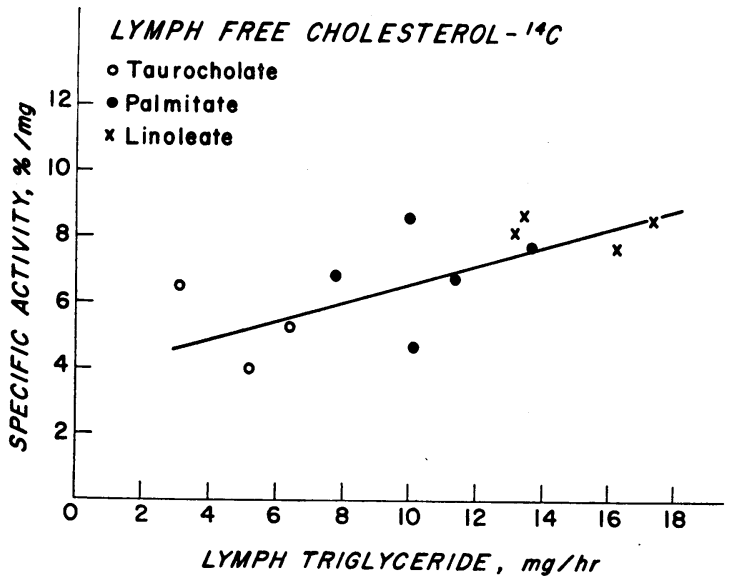

FIGURE 1 Effect of intraduodenal micelles on the specific activity of free cholesterol- ${ }^{14} \mathrm{C}$ in lymph (per cent of administered radioactivity per milligram of free cholesterol) at $0-3 \mathrm{hr}(\mathrm{r}=0.64, P<0.02)$.

glyceride plotted against lymph flow did not differ significantly from zero.

Ratio of specific activity of free: esterified cholesterol. The ratio of the specific activity of free vs. esterified cholesterol in lymph was calculated for each of the three groups of rats (see Fig. 2). The $0-3 \mathrm{hr}$ values were 0.45 \pm 0.03 for taurocholate, $0.87 \pm 0.06$ for linoleic acid, and $0.60 \pm 0.02$ for palmitic acid. The analysis of variance showed that there were very significant differences between the free: ester ratios in the three groups $(F=$ $132.5, P<0.01$ ), with the highest values occurring in the linoleic acid group. These differences were no longer significant during the 3-6 hr period, the corresponding ratios being $0.46 \pm 0.10,0.57 \pm 0.07$, and $0.56 \pm 0.08$ ( $F=$ $2.69, P>0.05)$.

Transport of vitamin $D_{s}$ into lymph. The effects of taurocholate and mixed micelles on vitamin $\mathrm{D}_{3}$ transport into lymph are shown in Table VII. The rats given

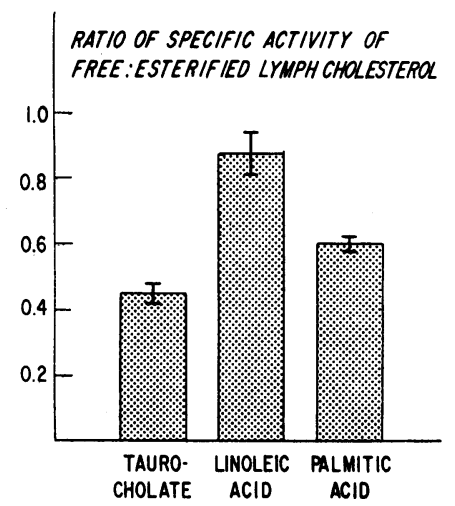

FIGURE 2 Effect of intraduodenal micelles on the ratio of specific activity of free: esterified cholesterol in lymph at $0-3 \mathrm{hr}$.
TABLE VII

Effect of Taurocholate Micelles or Mixed Micelles on the Appear. ance of Vitamin $D_{3^{-}}{ }^{3} \mathrm{H}$ in Lymph

\begin{tabular}{ccccc}
\hline & \multicolumn{3}{c}{ Per cent of administered radioactivity } \\
\cline { 2 - 5 } Micelles & $0-3 \mathrm{hr}$ & $3-6 \mathrm{hr}$ & $0-24 \mathrm{hr}$ & $\begin{array}{c}\text { Small } \\
\text { intestinal } \\
\text { wall } \\
24 \mathrm{hr}\end{array}$ \\
\cline { 2 - 5 } $\begin{array}{c}\text { Tymph* } \\
\text { (n = }=7) \S\end{array}$ & $16.3 \pm 3.1$ & $11.0 \pm 1.4$ & $42.9 \pm 6.4$ & $\begin{array}{c}3.2 \\
(1.3-6.3) \\
(\mathrm{n}=4)\end{array}$ \\
$\begin{array}{c}\text { Linoelic acid } \\
(\mathrm{n}=7)\end{array}$ & $27.7 \pm 8.0$ & $12.0 \pm 2.4$ & $53.9 \pm 10.8$ & $\begin{array}{c}4.7 \\
(0.8-12.0) \\
(\mathrm{n}=4)\end{array}$ \\
$\begin{array}{c}\text { Palmitic acid } \\
\text { (n=8) }\end{array}$ & $26.5 \pm 5.2$ & $12.3 \pm 3.1$ & $53.4 \pm 7.3$ & $\begin{array}{c}2.0 \\
(1.8-2.9) \\
(\mathrm{n}=4)\end{array}$ \\
& & & & \\
Analysis of & & & & \\
variance & $F=8.52$ & $F=0.63$ & $F=3.96$ & \\
\hline
\end{tabular}

* Mean \pm standard deviation.

$\ddagger$ Mean and range. Mean total recovery of radioactivity at $24 \mathrm{hr}$ (including large intestinal contents and feces) was $74.2 \%(n=8)$.

$\S \mathrm{n}=$ number of rats.

taurocholate absorbed $16.3 \%$ of the administered radioactivity into lymph within $3 \mathrm{hr}$. By contrast those given linoleic acid mixed micelles and palmitic acid mixed micells absorbed 27.7 and $26.5 \%$, respectively; this increase over the taurocholate group was highly significant $(P<0.01)$. This difference had completely disappeared after discontinuing the infusion of micelles. The relationship between the amounts of triglyceride and vitamin $D_{3}$ in lymph is shown in Fig. 3. Just as with labeled free cholesterol, there was a significant correlation between lymph triglyceride and the amount of vitamin $\mathrm{D}_{3}$ appearing in lymph $(r=0.58, P<0.01)$. This relationship was also independent of lymph flow since the slope of the regression of the ratio vitamin D:triglyceride plotted against lymph flow did not differ significantly from zero.

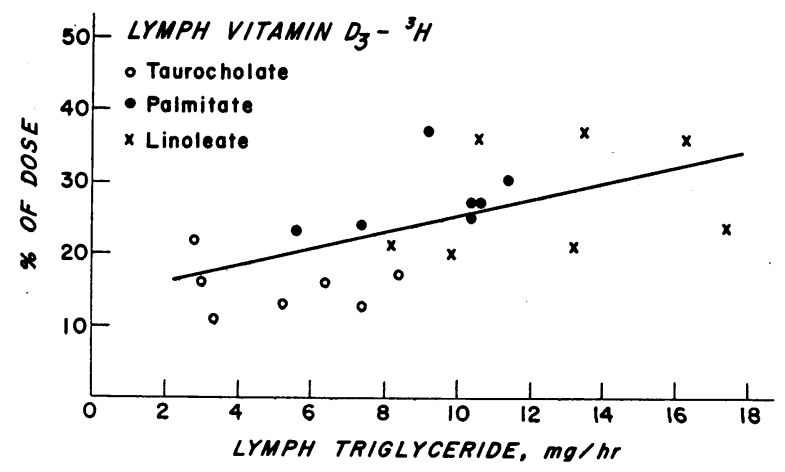

FIGURE 3 Effect of intraduodenal micelles on appearance of vitamin $\mathrm{D}_{3}{ }^{3} \mathrm{H}$ in lymph at $0-3 \mathrm{hr}(\mathrm{r}=0.58, P<0.01)$. 
The over-all absorption of vitamin $\mathrm{D}_{3}$ between 0 and $24 \mathrm{hr}$ was $42.9 \%$ for the taurocholate group compared to 53.9 and $53.4 \%$ for rats given mixed micelles. Although these differences were significant $(P<0.05)$, they simply reflected the changes which had occurred between 0 and $3 \mathrm{hr}$.

The amount of lipid-soluble radioactivity remaining in the wall of the small intestine at $24 \mathrm{hr}$ was similar in all three groups, mean values ranging from 2.0 to $4.7 \%$ of the administered dose. These values were lower than those for cholesterol. The over-all recovery of radioactivity at $24 \mathrm{hr}$ from lymph, intestine, and intestinal contents in rats given vitamin $\mathrm{D}_{3}{ }^{3} \mathrm{H}$ was $74.2 \%$.

\section{DISCUSSION}

This study demonstrates that the absorption of cholesterol and vitamin $\mathrm{D}_{3}$ in the rat can be influenced by the presence and simultaneous absorption of relatively small quantities of micellar lipid. It was shown that the intraduodenal administration of mixed micellar solutions of either linoleic acid or palmitic acid resulted in a significant increase in the specific activity of lymph free cholesterol, as compared to controls receiving taurocholate alone. This increase in the specific activity of free cholesterol was linearly correlated with a rise in lymph triglycerides and occurred during the $3 \mathrm{hr}$ period of infusion of mixed micelles. In contrast to lymph free cholesterol there was no significant difference in the specific activity of esterified cholesterol between the three groups of rats.

In all three groups there was a considerable degree of variation in the specific activity of both free and esterified cholesterol in the lymph of individual rats. In the case of free cholesterol, these variations were associated with differences in lymph triglyceride levels. However, there was remarkably little variation among the rats within each group when the specific activities of free and esterified cholesterol were expressed as a ratio, although there were marked differences between each of the three groups. These differences were present only during the actual period of administration of taurocholate or mixed micelles: the highest ratios occurred with linoleic acid micelles. This ratio of free: esterified cholesterol appeared to be independent of any quantitative changes in the lymph triglycerides.

It is well recognized that there is considerable exchange of free cholesterol which occurs across cell membranes, including the intestinal wall (11), and this factor may well have accounted for a significant portion of the radioactivity in lymph. However, the administration of mixed micellar solutions increased the appearance in lymph not only of labeled free cholesterol but also of vitamin $\mathrm{D}$, and both to a similar extent. In the case of vitamin $\mathrm{D}$, this increase almost certainly repre- sented enhanced absorption rather than exchange, since the mucosal pool of vitamin D is relatively small. This suggests that exchange was not the sole explanation for the cholesterol findings, but that increased absorption of labeled free cholesterol probably also occurred. The fact that there was no corresponding increase in the $0-3 \mathrm{hr}$ lymph total cholesterol probably reflects $(a)$ the relatively small amount of intraluminal cholesterol labeled during the initial $30 \mathrm{~min}$ period of micellar administration; $(b)$ the fact that only about one-third of cholesterol in lymph is free; $(c)$ that lymph cholesterol is partly derived from sources other than the intestinal lumen (21).

The changes observed among the three groups in the specific activity of lymph free cholesterol were unlikely to have been due to differences in the specific activity of luminal cholesterol, since in other experiments biliary cholesterol, a major component of endogenous luminal cholesterol, was found in similar amounts in animals receiving taurocholate micelles or mixed micelles (unpublished observations). The finding of a higher specific activity of esterified cholesterol in lymph compared to free cholesterol has also been observed by Swell, Trout, Hopper, Field, and Treadwell (22), who found that a similar relationship existed between free and esterified cholesterol within the intestinal wall. These authors considered that the lower specific activity of free cholesterol was due to its greater dilution by endogenous cholesterol within the mucosa. This and other evidence (23) supports the concept that there may be more than one pool of cholesterol within the intestinal wall. During the present study it was found that the ratio of the specific activity of free: esterified cholesterol was higher after the administration of linoleic acid than after taurocholate or palmitic acid. One possible explanation for this effect of linoleic acid is that it somehow increased the proportion of labeled cholesterol which mixed with the free cholesterol pool within the intestinal wall.

The dose of radioactive vitamin $D_{3}$ used to study vitamin D absorption was approximately $100 \mathrm{IU}$, which is somewhat high to be strictly physiological in the rat but is less than has been used in most previous studies of absorption. A similar effect was demonstrated in the case of vitamin $D_{3}$ as for free cholesterol, in that both linoleic and palmitic acid mixed micelles caused a significant increase in $0-3 \mathrm{hr}$ lymph radioactivity, this increase again being correlated with lymph triglyceride levels. The over-all increase in the $24 \mathrm{hr}$ absorption of vitamin $\mathrm{D}_{3}$ in these rats suggested that the rate of transport into lymph during the initial phase of absorption determined the total amount that was eventually absorbed. It is noteworthy that over $70 \%$ of the absorbed vitamin $D_{\mathbf{z}}$ was transported into lymph as unaltered free 
sterol, while most of the remaining radioactivity was more polar and presumably represented metabolites (24).

The intraduodenal infusion of $10 \mathrm{ml}$ of $20 \mathrm{~mm}$ taurocholate over $3 \mathrm{hr}$ did not cause any change in lymph triglycerides, although it has been shown that larger amounts of taurocholate may cause an increase in lymph triglycerides (25). Although the amount of taurocholate infused was relatively large in comparison with the total bile acid pool of the rat, this was necessary in order to dissolve an adequate amount of lipid in micellar solution. Furthermore, since the control group of rats received the same amount of taurocholate as the rats given mixed micelles it is unlikely that any differences between the groups were due to this factor. The dose of micellar lipid administered to the lymph fistula rats over the course of $3 \mathrm{hr}$ was equivalent to about $40 \mathrm{mg}$ of triglyceride, an amount comparable to that likely to be consumed by adult rats on a normal diet. Lymph triglycerides were found to be higher after linoleic acid mixed micelles than after palmitic acid mixed micelles, although this may well have been due to the higher basal level in the rats given linoleic acid mixed micelles. The fact that tracer doses of linoleic acid were more rapidly absorbed than tracer doses of palmitic acid from their respective mixed micellar solutions could have been due to a lower proportion of the palmitic acid being in micellar form, as suggested by the Millipore experiments (see Methods). However, other workers have found that the monounsaturated oleic acid, even when given as an emulsion, is better absorbed than palmitic acid micelles (26).

In order to determine the role of intestinal uptake in these experiments, rats with intact lymphatics were infused for $30 \mathrm{~min}$ with labeled sterol and then killed at 1 $\mathrm{hr}$. This time period was chosen since it has been shown in isolated loop experiments that vitamin $D_{s}$ uptake is virtually complete by then, whereas transport of the sterol out of the intestinal wall is still minimal (2). It was clearly shown that the uptake of both cholesterol and vitamin $\mathrm{D}_{3}$ into the intestinal wall was not significantly affected by the presence of mixed micelles as compared with taurocholate micelles. This implies that the enhanced rate of appearance of free cholesterol and vitamin $D_{3}$ in lymph after the administration of mixed micells was probably due to an effect on transport mechanisms within the intestinal wall rather than to an alteration in mucosal uptake.

Studies by Zilversmit (27) have shown that of the free cholesterol in lymph a greater percentage is in chylomicrons, as compared to the other lipoprotein fractions of lymph. This difference is most marked in the chylomicron surface coat, the cholesterol of which is entirely in the free form. Since lymph chylomicrons increase during fat absorption, it seem possible that the increase in radioactive free cholesterol after mixed mi- cells was the result of enhanced chylomicron formation. However, this interpretation would not apply to vitamin $\mathrm{D}$, which is not a known structural component of chylomicrons. It seems more likely that the increase in lymph radioactive free cholesterol and vitamin $\mathrm{D}$ reflects, at least in part, their molecular similarity, and is related to the physicochemical effects of triglyceride undergoing transport through the absorptive cell.

Zilversmit (27) found a higher proportion of free cholesterol in the chylomicrons of rats fed corn oil, which contain $50 \%$ linoleic acid, than in those fed cream. In the present study the administration of linoleic acid increased the specific activity lymph free cholesterol more than palmitic acid, although it was not possible to determine how much of this was due to enhanced absorption of label and how much to increased exchange. Conceivably, this contrast between the two fatty acids could have been due to a difference in their rate of esterification of cholesterol. However, Karmen, Whyte, and Goodman (28) found that both fatty acids were incorporated into chylomicron cholesterol ester to the same extent. These authors showed that the cholesterol in lymph was preferentially esterified with oleic acid, much of which was of endogenous rather than exogenous origin. Another possibility is that linoleic acid caused a more rapid entry of free cholesterol into lymph, and as a consequence diminished the amount available for esterification in the mucosa.

It has been shown that free cholesterol in chylomicrons equilibrates more rapidly than esterified cholesterol with cholesterol in other tissues, such as the liver $(29,30)$. Thus it is possible that an increase in the ratio of labeled free: esterified cholesterol in lymph, as demonstrated in the present studies, might influence the subsequent distribution and turnover rate of absorbed cholesterol. These and other recent findings (31) appear to indicate that saturated and unsaturated fatty acids differ in their effects on the transport of cholesterol into lymph.

\section{ACKNOWLEDGMENTS}

We would like to thank Mrs. G. D. Drummey and Mrs. Faith Hughes for excellent technical assistance. We gratefully acknowledge the assistance of Dr. R. Glickman in the preparation of some of the lymph fistula rats.

This work was supported in part by grants from the John A. Hartford Foundation, Inc. and the National Institutes of Health (AM-01392 and AM-03014). Dr. Thompson was in receipt of a Medical Research Council Travelling Fellowship.

\section{REFERENCES}

1. Chaikoff, I. L., B. Bloom, M. D. Siperstein, J. Y. Kiyasu, W. D. Reinhardt, W. G. Dauben, and J. E. Eastham. 1952. $C^{14}$-cholesterol. I. Lymphatic transport of absorbed cholesterol-4-C ${ }^{14}$. J. Biol. Chem. 194: 407. 
2. Schachter, D., J. D. Finkelstein, and S. Kowarski. 1964 Metabolism of vitamin D. I. Preparation of radioactive vitamin $\mathrm{D}$ and its intestinal absorption in the rat. $J$. Clin. Invest. 43: 787.

3. Daskalakis, E. G., and I. L. Chaikoff. 1955. The significance of esterification in the absorption of cholesterol from the intestine. Arch. Biochem. Biophys. 58: 373.

4. Bell, N. H. 1966. Comparison of intestinal absorption and esterification of 4-C $C^{14}$ vitamin $\mathrm{D}_{3}$ and 4-C $\mathrm{C}^{14}$ cholesterol in the rat. Proc. Soc. Exp. Biol. Med. 123: 529.

5. Kim, K. S., and A. C. Ivy. 1952. Factors influencing cholesterol absorption. Amer. J. Physiol. 171: 302.

6. Pihl, A. 1955. On the mode of action of fatty acids in cholesterol absorption. Acta Physiol. Scand. 34: 197.

7. Swell, L., D. F. Flick, H. Field, Jr., and C. R. Treadwell. 1955. Role of fat and fatty acid in absorption of dietary cholesterol. Amer. J. Physiol. 180: 124.

8. Vahouny, G. V., and C. R. Treadwell. 1959. Comparative effects of dietary fatty acids and triglycerides on lymph lipids in the rat. Amer. J. Physiol. 196: 881.

9. Knudson, A., and R. J. Floody. 1940. Fat as a factor in the healing of rickets with vitamin D. J. Nutr. 20: 317.

10. Goodman, D. S. 1965. Cholesterol ester metabolism. Physiol. Rev. 45: 747.

11. Simmonds, W. J., A. F. Hofmann, and E. Theodor. 1967. Absorption of cholesterol from a micellar solution: intestinal perfusion studies in man. J. Clin. Invest. 46: 874.

12. Thompson, G. R., B. Lewis, and C. C. Booth. 1966. Absorption of vitamin $\mathrm{D}_{\mathbf{8}}{ }^{3} \mathrm{H}$ in control subjects and patients with intestinal malabsorption. J. Clin. Invest. 45: 94.

13. Johnston, J. M., and B. Borgström. 1964. The intestinal absorption and metabolism of micellar solutions of lipids. Biochim. Biophys. Acta. 84: 412.

14. Hofmann, A. F., and D. M. Small. 1967. Detergent properties of bile salts: correlation with physiological function. Annu. Rev. Med. 18: 333 .

15. Hofman, A. F., and B. Borgström. 1962. Physico-chemical state of lipids in intestinal content during their digestion and absorption. Fed. Proc. 21: 43.

16. Bollman, J. L., J. C. Cain, and J. H. Grindlay. 1948. Techniques for the collection of lymph from the liver, small intestine or thoracic duct of the rat. J. Lab. Clin. Med. 33: 1349.

17. Bollman, J. L. 1948. A cage which limits the activity of rats. J. Lab. Clin. Med. 33: 1348.
18. Folch, J., M. Lees, and G. M. Sloane-Stanley. 1957. A simple method for the isolation and purification of total lipides from animal tissues. J. Biol. Chem. 226: 497.

19. van Handel, E., and D. B. Zilversmit. 1950. Micromethod for the direct determination of serum triglycerides. J. Lab. Clin. Med. 50: 152.

20. Zlatkis, A., B. Zak, and A. J. Boyle. 1953. A new method for the direct determination of serum cholesterol. J. Lab. Clin. Med. 41: 486.

21. Wilson, T. D., and R. T. Reinke. 1968. Transfer of locally synthesized cholesterol from intestinal wall to intestinal lymph. J. Lipid Res. 9: 85.

22. Swell, L., E. C. Trout, R. Hopper, H. Field, and C. R. Treadwell. 1959. The mechanism of cholesterol absorption. Ann. N. Y. Acad. Sci. 72: 813 .

23. Sodhi, H. S., V. Berger, and R. G. Gould. 1967. Evidence for the two pools of cholesterol in small intestine. Fed. Proc. 26: 471 .

24. Lund, J., and H. F. DeLuca. 1966. Biologically active metabolite of vitamin $\mathrm{D}_{3}$ from bone, liver and blood serum. J. Lipid Res. 7: 739.

25. Redgrave, T. G. 1967. The absorption of micellar lipid into the lymph of unanesthetized rats. Quart. J. Exp. Physiol. 52: 130.

26. Simmonds, W. J., T. G. Redgrave, and R. L. S. Willix. 1968. Absorption of oleic and palmitic acids from emulsions and micellar solutions. J. Clin. Invest. 47: 1015.

27. Zilversmit, D. B. 1965. The composition and structure of lymph chylomicrons in dog, rat and man. J. Clin. Invest. $44: 1610$.

28. Karmen, A., M. Whyte, and D. S. Goodman. 1963. Fatty acid esterification and chylomicron formation during fat absorption. I. Triglycerides and cholesterol esters. J. Lipid Res. 4: 312.

29. Lossow, W. T., N. Brot, and I. L. Chaikofi. 1962. Disposition of the cholesterol moiety of a chylomicroncontaining lipoprotein fraction of chyle in the rat. $J$. Lipid Res. 3: 207.

30. Naidoo, S. S., W. T. Lossow, and I. L. Chaikoff. 1962. Disappearance of the cholesterol moiety of an injected chylomicron-containing fraction of chyle from the circulation of the rat. J. Lipid Res. 3: 309.

31. Ockner, R. K., and K. J. Isselbacher. 1968. Intestinal lymph very low density lipoprotein: role in cholesterol metabolism. J. Clin. Invest. 47: 73a. 